\title{
The influence of temperature, light energy and photoperiod on flowering of Brodiaea laxa Wats. ${ }^{1}$
}

\author{
E. J. Fortanier
}

Department of Horticulture, Agricultural University, Wageningen, the Netherlands

Received 10 February 1969

\begin{abstract}
Summary
Temperature and light requirements for a satisfactory forcing of Brodiaea laxa 'Koningin Fabiola' were studied. Corms were planted under different temperature and light conditions in a phytotron and in different photoperiods in the open. Long day accelerated flower development and the termination of growth and enhanced corm formation. Considering both earliness and number of flowers, the most acceptable results with regard to flower production were obtained at $18^{\circ} \mathrm{C}$ in short photoperiods. Forcing at higher temperatures and in longer photoperiods resulted in a decrease in the number of flowers because of bud blasting. This was even the case when short day was extended by high light intensities. Early and retarded corms reacted similarly but the latter flowered sooner and more satisfactorily. Flowering was preceded under all conditions by corm formation and in longer photoperiods even by senescence of the leaves. Year round production of flowers will be possible if $25 \mathrm{cal}^{\mathrm{cm}} \mathrm{cm}^{-2}$. day-1 of light energy or more are available.
\end{abstract}

\section{Introduction}

Brodiaea is a rather extensive and heterogeneous genus. Brodiaea laxa Wats. (Triteleia laxa Benth.) is the most important species grown in the Netherlands (Krabbendam and Baardse, 1967). Little is known about its requirements for satisfactory and rapid flowering. The conditions before and after planting which we refer to as storage and forcing conditions, are both of importance. This study is only concerned with forcing conditions.

\section{Materials and methods}

All experiments were done with Brodiaea 'Koningin Fabiola' 2 , a mutant from $B$. laxa. Corms were lifted in the field in August 1966 and selected for uniform size with an average weight of $2.6 \mathrm{~g}$. They were subjected to two storage treatments, one for early forcing $\left(11\right.$ weeks $23^{\circ} \mathrm{C}+7$ weeks $\left.5^{\circ} \mathrm{C}\right)$, the other for late forcing ( 40 weeks $23^{\circ} \mathrm{C}+4$ weeks $5^{\circ} \mathrm{C}$ ). This was done to discover whether or not the requirements

1 Publication 325, Laboratorium voor Tuinbouwplantenteelt, Landbouwhogeschool, Wageningen, the Netherlands.

2 Obtained from the Royal Netherlands Bulb Nurseries, Van Zanten Brothers, Hillegom, the Netherlands. 
for forcing are affected by storage conditions. At the end of both treatments roots and sprouts had begun to grow. These early and retarded corms were planted in soil immediately after storage in 5 liter plastic pots on 11 January and 17 July 1967 respectively.

After planting the treatments represented in Table 1 were started. To study the temperature requirements for forcing, the early planted corms were placed at temperatures of $9,12,15,18,21$ or $24^{\circ} \mathrm{C}$ in a phytotron. To study the light requirements, the plants should have been placed in different light intensities, but because these conditions could not be provided, each temperature treatment was combined with 8 or 16 hours of artificial light or with daylight. Those which received daylight, acted as a practical control and are abbreviated as DL. To compare the requirements of early and retarded corms, the treatments at 15,18 and $21^{\circ} \mathrm{C}$ were repeated with the retarded corms. At that time the temperatures in the daylight rooms were disturbed by the summer conditions. Therefore the DL treatments were replaced by artificial light, given continuously. The treatments in artificial light are abbreviated as $8 \mathrm{TL}$, $16 \mathrm{TL}$ and $24 \mathrm{TL}$ and correspond with 27,54 and $81 \mathrm{cal}^{\mathrm{cm}} \mathrm{cm}^{-2}$. day-1 of light energy. The irradiation with an intensity of $40,000 \mathrm{ergs} . \mathrm{cm}^{-2}$. $\mathrm{sec}^{-1}$ was provided by Philips TL $40 \mathrm{~W} / 55$ lamps. Each treatment involved at least 18 corms planted in 3 pots.

Different results in the $8 \mathrm{TL}, 16 \mathrm{TL}, 24 \mathrm{TL}$ and $\mathrm{DL}$ treatments, might be ascribed to differences in the daily light energy, or to differences in the length of the photoperiod, or to both factors. Therefore, retarded corms were placed in photoperiods of $8,12,16$ and 20 hours. This was achieved by extending 8 hours of sunlight in the open from 8.30 A.M. till 4.30 P.M., with $0,4,8$ and 12 hours of incandescent light $(8+0,8+4,8+8,8+12)$. This irradiation had an intensity of $400 \mathrm{ergs} . \mathrm{cm}^{-2} \cdot \mathrm{sec}^{-1}$ and was given in four darkrooms. To compare the development and distribution of dry weight, 12 plants from each photoperiod treatment were harvested fortnightly, on six occasions. These plants were partioned into old and new corm, cormlets, leaves and inflorescences, and dried at $80^{\circ} \mathrm{C}$ till constant weight.

The treatments of the early planted corms were continued until the foliage had died, but treatments given to the retarded corms had to be terminated after flowering, because of worsening weather conditions, affecting the plants growing in the open.

\section{Experimental results}

For all the treatments data were collected on the date when each inflorescence opened its first and last flower, the number of plants with one or two inflorescences, the number of flowers and blasted buds per umbel, the length of the scape and the number of leaves and cormlets which formed. The most important data on flowering are presented in Table 1. The average daily light energies received until flowering, are also included.

\section{Retardation and temperature}

The data for similar treatments of early and retarded corms demonstrate that the retarded corms flowered more quickly, with a higher percentage of second inflorescences, with more flowers in the first umbel and with longer scapes than early corms. From this it was concluded that the retardation treatment had stimulated a more rapid and abundant flowering. Higher temperatures accelerated flowering but decreased the percentage of plants with one or two inflorescences, and decreased the number 
Table 1 Effects of temperature, light and photoperiod on flowering of early and retarded corms of Brodiaea 'Koningin Fabiola'

\begin{tabular}{|c|c|c|c|c|c|c|}
\hline \multirow[t]{2}{*}{ Treatment } & \multirow{2}{*}{$\begin{array}{c}\text { Date } \\
\text { first } \\
\text { flowering }\end{array}$} & \multicolumn{2}{|c|}{ Flowering (\%) } & \multicolumn{2}{|c|}{ 1st inflorescence } & \multirow{2}{*}{$\begin{array}{c}\text { Energy received } \\
(\text { cal.cm-2.day-1) }\end{array}$} \\
\hline & & $\begin{array}{c}\text { first } \\
\text { inflor. }\end{array}$ & $\begin{array}{l}\text { second } \\
\text { inflor. }\end{array}$ & $\begin{array}{c}\text { number of } \\
\text { flowers }\end{array}$ & $\begin{array}{l}\text { scape } \\
(\mathrm{cm})\end{array}$ & \\
\hline
\end{tabular}

Early corms, planted $11 / 1 / 67$ in phytotron

\begin{tabular}{|c|c|c|c|c|c|c|c|}
\hline $9^{\circ} \mathrm{C}$ & $\begin{array}{r}8 \mathrm{TL} \\
16 \mathrm{TL} \\
\mathrm{DL}\end{array}$ & $\begin{array}{c}7 / 10 \\
18 / 8 \\
9 / 8\end{array}$ & $\begin{array}{l}100 \\
100 \\
100\end{array}$ & $\begin{array}{l}5 \\
0 \\
0\end{array}$ & $\begin{array}{l}21 \\
17 \\
16\end{array}$ & $\begin{array}{l}55 \\
46 \\
42\end{array}$ & $\begin{array}{l}27 \\
54 \\
74\end{array}$ \\
\hline $12^{\circ} \mathrm{C}$ & $\begin{array}{rl}8 & \mathrm{TL} \\
16 & \mathrm{TL} \\
& \mathrm{DL}\end{array}$ & $\begin{array}{r}16 / 8 \\
24 / 6 \\
5 / 7\end{array}$ & $\begin{array}{l}100 \\
100 \\
100\end{array}$ & $\begin{array}{l}4 \\
0 \\
0\end{array}$ & $\begin{array}{l}16 \\
13 \\
16\end{array}$ & $\begin{array}{l}51 \\
48 \\
32\end{array}$ & $\begin{array}{l}27 \\
54 \\
681\end{array}$ \\
\hline $15^{\circ} \mathrm{C}$ & $\begin{array}{rl}8 & \mathrm{TL} \\
16 \mathrm{TL} \\
\\
\mathrm{DL}\end{array}$ & $\begin{array}{r}29 / 6 \\
18 / 5 \\
5 / 6\end{array}$ & $\begin{array}{l}100 \\
100 \\
100\end{array}$ & $\begin{array}{l}0 \\
0 \\
0\end{array}$ & $\begin{array}{l}14 \\
11 \\
15\end{array}$ & $\begin{array}{l}55 \\
49 \\
35\end{array}$ & $\begin{array}{l}27 \\
54 \\
591\end{array}$ \\
\hline $18^{\circ} \mathrm{C}$ & $\begin{array}{rr}8 \mathrm{TL} \\
16 \mathrm{TL} \\
\\
\mathrm{DL}\end{array}$ & $\begin{array}{r}5 / 6 \\
27 / 4 \\
18 / 5\end{array}$ & $\begin{array}{l}100 \\
100 \\
100\end{array}$ & $\begin{array}{l}0 \\
0 \\
0\end{array}$ & $\begin{array}{l}16 \\
12 \\
13\end{array}$ & $\begin{array}{l}50 \\
50 \\
34\end{array}$ & $\begin{array}{l}27 \\
54 \\
541\end{array}$ \\
\hline $21^{\circ} \mathrm{C}$ & $\begin{array}{rl}8 & \mathrm{TL} \\
16 & \mathrm{TL} \\
& \mathrm{DL}\end{array}$ & $\begin{array}{r}23 / 5 \\
17 / 4 \\
6 / 5\end{array}$ & $\begin{array}{r}100 \\
86 \\
100\end{array}$ & $\begin{array}{l}0 \\
0 \\
0\end{array}$ & $\begin{array}{r}9 \\
8 \\
12\end{array}$ & $\begin{array}{l}40 \\
42 \\
27\end{array}$ & $\begin{array}{l}27 \\
54 \\
48\end{array}$ \\
\hline $24^{\circ} \mathrm{C}$ & $\begin{array}{r}8 \mathrm{TL} \\
16 \mathrm{TL} \\
\mathrm{DL}\end{array}$ & $\begin{array}{r}18 / 5 \\
8 / 4 \\
23 / 4\end{array}$ & $\begin{array}{l}43 \\
15 \\
70\end{array}$ & $\begin{array}{l}0 \\
0 \\
0\end{array}$ & $\begin{array}{r}9 \\
6 \\
10\end{array}$ & $\begin{array}{l}37 \\
37 \\
30\end{array}$ & $\begin{array}{l}27 \\
54 \\
40^{1}\end{array}$ \\
\hline
\end{tabular}

Retarded corms, planted $17 / 7 / 67$ in phytotron

$\begin{array}{rrrrrrrr}15^{\circ} \mathrm{C} & 8 \mathrm{TL} & 21 / 11 & 100 & 71 & 18 & 57 & 27 \\ & 16 \text { TL } & 23 / 10 & 100 & 50 & 16 & 55 & 54 \\ & 24 \mathrm{TL} & 20 / 10 & 100 & 58 & 15 & 54 & 81 \\ 18^{\circ} \mathrm{C} & 8 \mathrm{TL} & 8 / 11 & 100 & 64 & 17 & 52 & 27 \\ & 16 \text { TL } & 5 / 10 & 100 & 64 & 16 & 55 & 54 \\ & 24 \mathrm{TL} & 28 / 9 & 100 & 44 & 15 & 45 & 81 \\ 21^{\circ} \mathrm{C} & 8 \mathrm{TL} & 27 / 10 & 100 & 33 & 14 & 41 & 27 \\ & 16 \text { TL } & 24 / 9 & 100 & 8 & 10 & 45 & 54 \\ & 24 \mathrm{TL} & 13 / 9 & 100 & 6 & 11 & 46 & 81\end{array}$

Retarded corms, planted $17 / 7 / 67$ outside

$\begin{array}{lcccccc}8+0 & 27 / 10 & 100 & 31 & 16 & 26 & 641 \\ 8+4 & 24 / 10 & 100 & - & 13 & 23 & 66 \pm 1 \\ 8+8 & 2 / 10 & 100 & 9 & 14 & 23 & 741 \\ 8+12 & 29 / 9 & 100 & 6 & 11 & 26 & 75 \pm\end{array}$

I Light energy calculated from data of the Department of Meteorology, Agricultural University, Wageningen, the Netherlands.

of flowers per umbel and the length of the scape. Early and retarded corms reacted similarly.

Light energy and temperature

On studying the effects of light energy and comparing the treatments with 8,16 and 24 TL, it was concluded that longer irradiations accelerated flowering, decreased flowering percentage and the number of flowers per umbel. It also decreased the 
length of the scape, but only at lower temperatures. The effects of DL resembled those of $8 \mathrm{TL}$ at high temperatures and those of $16 \mathrm{TL}$ at lower temperatures. This change in the effects of DL could be explained by the gradual increase in energy of daylight and in the length of the photoperiod, as time progressed. The average energy and its duration received by the plants untill flowering, increased from about 40 cal. $\mathrm{cm}^{-2}$. day-1 and 10 hours to about $74 \mathrm{cal}^{-\mathrm{cm}^{-2}}$. day-1 and 13 hours for plants grown in temperatures of 24 and $9^{\circ} \mathrm{C}$ respectively. Termination of growth was also affected. In all the treatments with irradiations longer than 8 hours, leaves were already yellowing at the onset of flowering. In fact, early corms planted at 21 and $24^{\circ} \mathrm{C}$ in $16 \mathrm{TL}$ flowered after the leaves had died.

The acceleration of flowering by higher temperatures and longer irradiations is represented by the curves in Fig. 1. These indicate that temperatures of 9 and $24^{\circ} \mathrm{C}$ can be considered as marginal; temperatures below $9^{\circ} \mathrm{C}$ will delay flowering too much, while those above $24^{\circ} \mathrm{C}$ will produce little further acceleration. Early and retarded corms reacted similarly. For reasons mentioned, the DL curve clearly shifts from the $16 \mathrm{TL}$ curve to the $8 \mathrm{TL}$ curve at higher temperatures.

Photoperiod and development of dry weight

Regarding the effects of longer photoperiods, the figures at the bottom of Table 1 demonstrate that flowering was accelerated and that flowering percentage and number

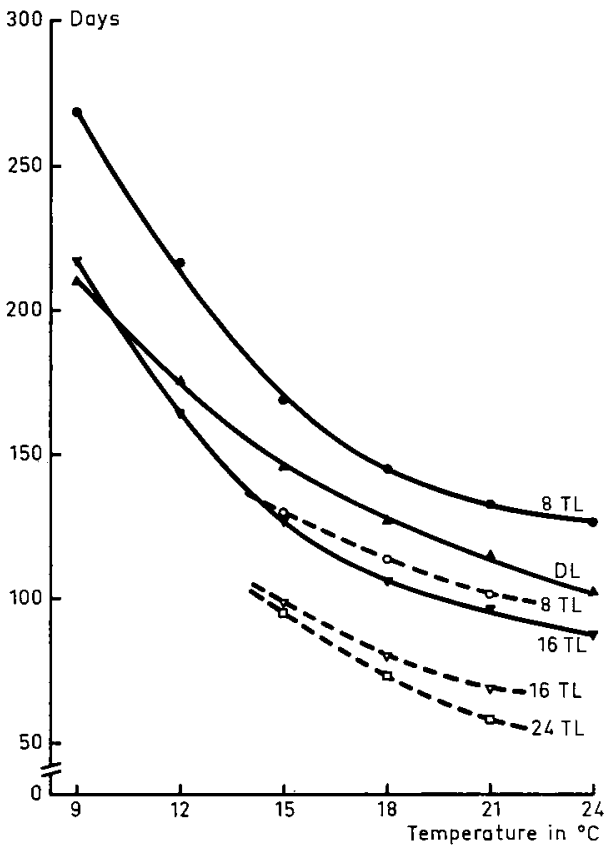

Fig. 1 Effect of temperature on number of days from planting till flowering of the first inflorescence, in 8, 16 and 24 hours of TL light and in daylight (DL). Full drawn curves for early corms, planted 11/1/67. Broken curves for retarded corms, planted 17/7/67.

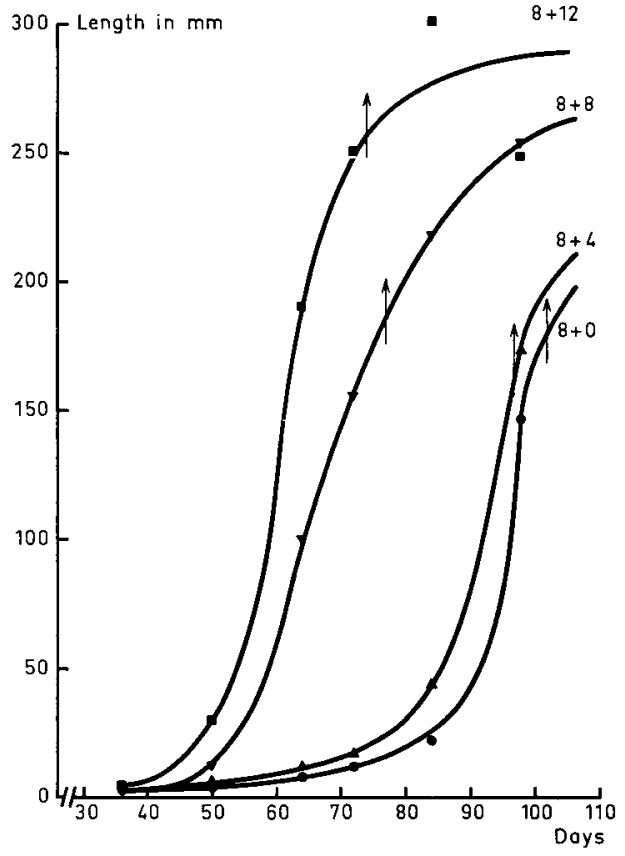

Fig. 2 The elongation of the first scape of retarded corms at photoperiods obtained by extending 8 hours of sunlight with $0,4,8$ and 12 hours of weak incandescent light. Absciss: number of days from planting. Arrows indicate time of first flowering. 
of flowers per umbel were diminished. The length of the scape at the end of flowering was not affected. The curves in Fig. 2 represent the rate of elongation of the scape in the four photoperiods. Data from the periodical harvests and measurements demonstrated that by 36 days after planting, the corms in each photoperiod had initiated their first and second inflorescence. No differences in the size and length of the first inflorescence could then be observed. Thus, it was only the elongation of the inflorescence which was affected by the length of the photoperiod. Photoperiods of $8+4$ and $8+0$ delayed the onset of elongation by about 25 days, explaining the difference in time of flowering.

The effects of the photoperiod on the change and distribution of the dry weight are demonstrated in Fig. 3. Only the curves for $8+0$ and $8+12$ are presented because those for $8+4$ and $8+8$ occupy intermediate positions. These demonstrate that all the processes such as the depletion of the old corm, the formation of leaves and new corm plus cormlets and the growth of the inflorescence, were accelerated by longer photoperiods. The dry weights of all parts increased more quickly in the longer photoperiods but reached lower maximum values. The sequence of these activities was not affected, with the exception of leaf senescence. Leaves of corms in photoperiods longer than $8+0$ hours started to yellow before flowering. The dry weight of the leaves in $8+12$ decreased long before the opening of the first flower, indicated by the arrow. In $8+0$ the leaves remained green till after flowering.

\section{Aspects of flowering}

The poorer flowering at higher temperatures and in longer irradiations or photoperiods was accompanied by a greater number of inflorescences which terminated their development prematurely. This phenomenon of withered flower buds is called bud blasting. Initiation and development of the inflorescence were not studied in detail. Therefore it can only be stated that blasting of flower buds was at least partly the cause of a decrease in flowering percentage and in number of flowers per umbel, under the conditions mentioned.

\section{Discussion}

The plants from early and retarded corms reacted similarly to variations in temperature and light, but the retarded ones flowered more quickly and more abundantly. Many other bulbs and corms grow and flower more quickly after retardation, but with poorer results in flowering. Iris may be mentioned as an example (Hartsema, 1961). Experiments with different storage temperatures at the Experimental Station in Naaldwijk (Anon., 1953) did not indicate a specific temperature requirement of Brodiaea for flowering, apart from the fact that a prolonged storage at $20^{\circ} \mathrm{C}$ delayed flowering and diminished the number of flowers. Nevertheless the possibility cannot be ruled out that the early corms in our experiments had not been stored long enough for optimal flowering. This needs further investigation.

Higher forcing temperatures accelerated flowering. This is a rather general phenomenon and needs no further discussion. An extension of $8 \mathrm{TL}$ to $16 \mathrm{TL}$ or to $24 \mathrm{TL}$ also accelerated flowering. A similar effect was obtained when photoperiods of 8 hours of sunlight were extended with weak incandescent light. The acceleration by longer irradiations must therefore be attributed primarily to differences in the photoperiod rather than to differences in light energy. This also explains the shifting of the DL 
curve in Fig. 1. The question as to what extent time of flowering was also affected by light energy cannot be answered. Apart from flowering, many other processes in Brodiaea such as flower development, corm formation and termination of growth were accelerated by longer photoperiods.

At higher temperatures and in longer photoperiods, even when the latter resulted in higher amount of daily light energy, the number of inflorescences and flowers that did not complete their development, increased. This phenomenon of flower blasting is well-known in many bulbous and cormous plants. It can be induced by water deficiency, temperatures that are either too low or too high, and by unfavourable light conditions (Hartsema, 1961; Kamerbeek, 1966). Higher temperatures accelerate growth, which increases the daily requirements for e.g. water and assimilates. This explains why in some cases flower blasting at higher temperatures can be prevented or diminished by increased light energy. This was not the case in these experiments with Brodiaea, probably because extended irradiations led to an earlier flowering and an earlier senescence of the leaves even before flowering. In the treatments with longer photoperiods, flowering must therefore have been achieved by drawing to a greater extent on energy from the reserves. This explains why in Fig. 3 not only the dry weight of the leaves but also that of the newly formed corms decreases in long photoperiods.

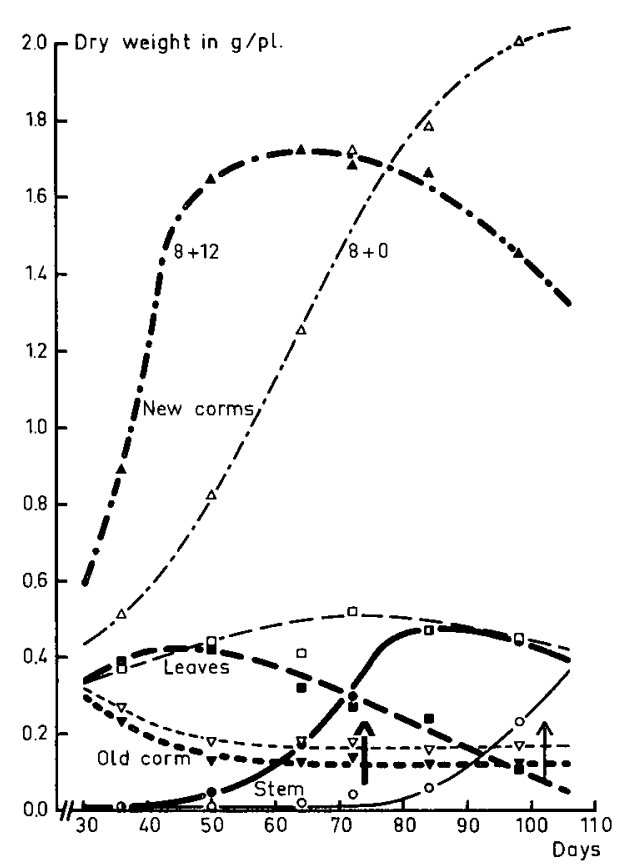

Fig. 3 Dry weight of old and new corms, leaves and stem plus inflorescence of Brodiaea, in photoperiods of $8+0$ hours (thin curves) and $8+12$ hours (thick curves). Absciss: number of days from planitng. Arrows indicate time of first flowering.

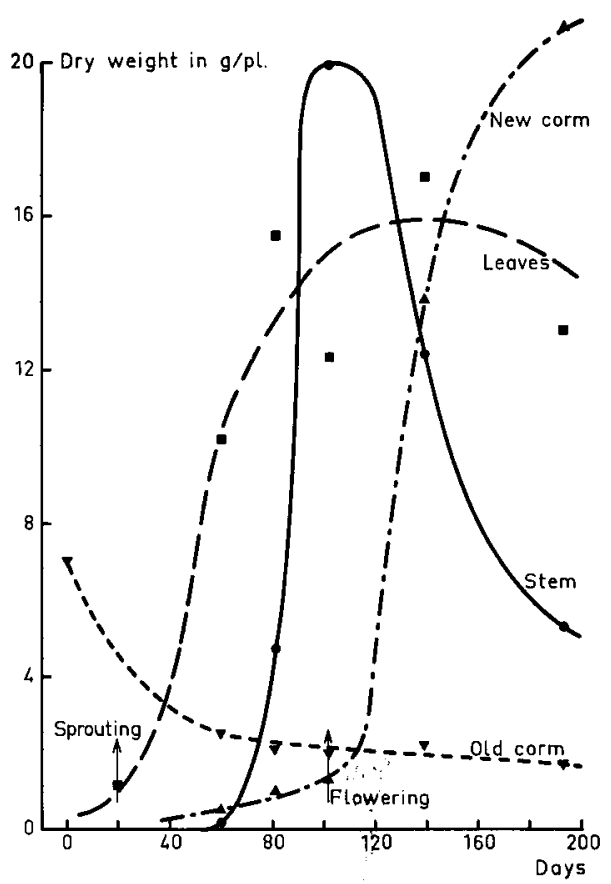

Fig. 4 Dry weight of old and new corms, leaves and stem of gladiolus planted 23/4/1959 in the open. Absciss: number of days from planting. Data from Wassink (1960), curves idealized. 
Under all the conditions investigated, flowering was preceded by corm formation. This is the converse of the sequence in many other crops like tulip, iris, gladiolus and freesia. Fig. 4 shows the distribution of dry weight in gladiolus as an example. The difference is interesting from an ecological point of view. Brodiaea seems especially adapted to environmental conditions, which worsen as the time of flowering approaches. Brodiaea has all its leaves arising from the new corm, while the others have all or most of their leaves arising from the stem. This may be decisive as to which develops first, corms or flowers. No information was found to check this hypothesis. Leopold (1961) discussed the death of plants or plant parts as being of positive ecological value. He stated that there is growing evidence to suggest that mobilizing forces are involved in the senescence signals. Reproductive organs of plants are among the most affectual mobilizing centres.

According to Table 1, flowers were produced from the beginning of April till the end of November. Although the effects of different amounts of light energy could not be studied because these were obscured by the effects of differences in the photoperiod, it is clear that light requirement for flowering is low. A daily amount of energy of $27 \mathrm{cal}^{\mathrm{cm}} \mathrm{cm}^{-2}$ was sufficient for $100 \%$ flowering with well filled umbels, even at temperatures of $21^{\circ} \mathrm{C}$. From these findings it is considered that all the year round production of flowers under the prevailing light conditions of the Netherlands should be possible. For rapid and satisfactory forcing, temperatures of $18^{\circ} \mathrm{C}$ and short photoperiods can be recommended, especially when light conditions are poor.

\section{Acknowledgments}

The author is indebted to Miss M. E. Marston and to 'Oud Cursisten Publiceren 1968' for their comments on the draft of this paper.

\section{References}

Anonymous, 1953. Bewaartemperatuurproef met Brodiaea. JVersl. Proefstn Groente- en Fruitteelt Glas Naaldwijk 1953: 29-30.

Hartsema, A. M., 1961. Influence of temperatures on flower formation and flowering of bulbous and tuberous plants. In: W. Ruhland (Ed.), Encyclopedia of plant physiology, Vol. 16. Springer, Berllin, p. 123-167.

Kamerbeek, G. A., 1966. Influence of light, temperature and other factors on bud blast of Dutch irisis. Proc. XVIIth Int. hort. Congr., Maryland 1: 233.

Krabbendam, P. en Baardse, A. A., 1967. Bloembollenteelt, deel VII: Bijgoed. Tjeenk Willink, Zwolle, p. 54-61.

Leopold, A. C., 1961. Senescence in plant development. Science 134: 1727-1732.

Wassink, E. C., 1960. The effect of light intensity on growth and development of Gladiolus. Proc. 3rd Int. photobiol. Congr., Copenhagen: 371-378. 